\title{
PEMANFAATAN KULIT KACANG DAN BULU AYAM SEBAGAI BAHAN ALTERNATIF PEMBUATAN KERTAS MELALUI CHEMICAL PULPING DENGAN MENGGUNAKAN $\mathrm{NaOH}$ DAN CaO
}

\author{
Aminah Asngad, Inna Siti N, Suci Siska \\ Prodi Pendidikan Biologi FKIP Universitas Muhammadiyah Surakarta \\ Jl. Ahmad Yani Tromol Pos 1 Pabelan Kartasura Surakarta \\ E-mail korespondensi: aminah.asngad@ums.ac.id
}

\begin{abstract}
Abstrak - Kertas pada umum merupakan bahan yang tipis dan rata yang biasanya terbuat dari kayu dengan kadar serat selulosa 39\%. Maka dapat diprediksikan bahwa akan terjadi eksploitasi hutan secara besar-besaran yang dapat mengakibatkan terganggunya kestabilan lingkungan sehingga perlu mendapat perhatian khusus dan mencari alternatif dengan bahan lain. Bahan alternatif yang dapat digunakan antara lain jerami, ampas tebu, merang, pelepah pohon pisang, kulit kacang dan bulu ayam dan kulit kacang. Pada pembuatan kertas, penambahan larutan $\mathrm{NaOH}$ atau $\mathrm{CaO}$, berfungsi untuk melarutkan lignin saat proses pembuburan (pulping) sehingga mempercepat proses pemisahan dan pemutusan serat. Penelitian ini bertujuan 1). Untuk mengetahui ketahanan tarik dan ketahanan sobek kertas dari kulit kacang dengan penambahan bulu ayam melalui Chemical Pulping (proses Kimia) dengan menggunakan $\mathrm{NaOH}$ dan $\mathrm{CaO}$ yang berbeda.2). Untuk mengetahui uji sensoris kertas dari kulit kacang dengan penambahan bulu ayam melalui Chemical Pulping (proses Kimia) dengan menggunakan $\mathrm{NaOH}$ dan $\mathrm{CaO}$.Penelitian dilakukan di Lab. Biokimia Prodi. Pend. Biologi UMS dan lab. UGM. Penelitian ini menggunakan metode eksperimen dengan rancangan acak lengkap (RAL) pola faktorial dengan 2 faktor. Teknik pengumpulan data dalam penelitian ini adalah deskriptif kualitatif. Parameter yang di ukur: Uji Ketahanan Tarik dan Uji Ketahanan Sobekdengan menggunakan Micrometer dan program Universal Testing Machine serta Pengujian Sensoris menggunakan panelis sebanyak 20 orang. ketahanan tarik paling tinggi pada perlakuan $\mathrm{J}_{1} \mathrm{~A}_{1}$ (Bahan kimia $\mathrm{NaOH} 15 \%$ dan Bulu ayam 50\% : Kulit Kacang 50\%)dengan rata-rata ketahanan $2.3531 \mathrm{~N}$, diikuti dengan $\mathrm{J}_{1} \mathrm{~A}_{2}(2.2732 \mathrm{~N}), \mathrm{J}_{2} \mathrm{~A}_{1}(2.1591 \mathrm{~N}), \mathrm{J}_{2} \mathrm{~A}_{2}(1.0875 \mathrm{~N}), \mathrm{J}_{1} \mathrm{~A}_{3}(0.9657 \mathrm{~N})$, $\mathrm{J}_{2} \mathrm{~A}_{3}(0.7433 \mathrm{~N})$. ketahanan sobek paling tinggi pada perlakuan $\mathrm{J}_{1} \mathrm{~A}_{1}$ (Bahan kimia $\mathrm{NaOH}$ $15 \%$ dan Bulu ayam 50\% : Kulit Kacang 50\%)dengan rata-rata ketahanan $9.2773 \mathrm{~N}$, diikuti dengan $\mathrm{J}_{1} \mathrm{~A}_{2}(6.9535 \mathrm{~N}), \mathrm{J}_{1} \mathrm{~A}_{3}(3.9324 \mathrm{~N}), \mathrm{J}_{2} \mathrm{~A}_{1}(3.4954 \quad \mathrm{~N}), \mathrm{J}_{2} \mathrm{~A}_{2}(1.9079 \mathrm{~N}), \mathrm{J}_{2} \mathrm{~A}_{3}$ (1.6277 N).Dari hasil penelitian dapat disimpulkan adanya perbedaan ketahanan tarik, ketahanan sobek, maupun hasil uji organoleptik kertas dari Kulit Kacang dan Bulu Ayam Melalui Chemical Pulping (proses Kimia) Dengan Menggunakan $\mathrm{NaOH}$ dan $\mathrm{CaO}$
\end{abstract}

Kata kunci: Kulit kacang, bulu ayam, kertas, $\mathrm{NaOH}$ dan $\mathrm{CaO}$ 


\section{PENDAHULUAN}

Kertas pada umumnya merupakan bahan yang tipis dan rata yang biasanya terbuat dari kayu dengan kadar serat $39 \%$. Penggunaan kertas di dunia saat ini telah mencapai angka yang sangat tinggi. Berdasarkan data Kementerian Perindustrian Republik Indonesia, pada tahun 2012 permintaan kertas mencapai 12 juta ton. Zulfikar (2011) mengemukakan 90\% pulp dan kertas yang dihasilkan menggunakan bahan baku kayu sebagai sumber bahan berserat selulosa. Maka dapat diprediksikan bahwa akan terjadi eksploitasi hutan secara besar-besaran yang dapat mengakibatkan terganggunya kestabilan lingkungan sehingga perlu mendapat perhatian khusus. Untuk mengatasi hal ini pemerintah harus mencari alternatif untuk mengganti penggunaan kayu hutan sebagai bahan baku pembuat pulp dan kertas.

Bahan alternatif yang dapat digunakan antara lain jerami dengan kadar selulosa 30,2 \%, ampas tebu dengan kadar selulosa $43-52 \%$ (Nasution, 2010), merang dan pelepah pohon pisang, daun kulit kacang dan bulu ayam dan kulit kacang dengan kadar selulosa 63,5\% (Murni, 2008).

Menurut Purnawan dkk (2012) bahwa hasil penelitian dengan menggunakan ampas tebu sebagai bahan alternatif pembuat kertas dekorasi menggunakan metode organosolv dengan pelarut organik diperoleh bahwa semakin besar jumlah etanol (larutan pemasak) ampas tebu yang diperoleh semakin halus dan lunak. Menurut hasil penelitian Prabawati dkk (2008) bahwa merang dan pelepah pohon pisang dapat dimanfaatkan sebagai bahan alternatif pembuatan kertas yang ramah lingkungan dan kertas yang dihasilkan dari kedua bahan tersebut mempunyai keungulan yang terletak pada corak dan warnanya yang khas. Sedangkan menurut
Syamsu dkk (2012) selulosa micobial dari nata de cassava dapat dikombinasikan dengan sabut kelapa untuk dijadikan sebagai bahan baku kertas.

Sejauh ini, pemanfaatan kacang tanah masih terbatas pada pengolahan bijinya saja yang kemudian diolah menjadi produk makanan ringan atau bumbu masakan. Sementara itu, kulitnya belum dimanfaatkan secara maksimal. Kulit kacang tanah umumnya hanya menjadi limbah atau sebagai pakan ternak dan sebagai bahan dasar pembuatan asap cair (liquid smoke) antioksidan (Pertiwi, 2011), briket untuk bahan bakar alternatif (Eko, 2010), dan pupuk organik (Dahlan dan Darmansyah, 2011).

Sekitar 30\% dari buah kacang tanah berupa kulit dengan kandungan serat selulosa pada kulit kacang tanah sebesar 63,5\% (Murni, 2008). Berdasarkan data BPS pada tahun 2012, jumlah kacang tanah yang dipasok ke industri kacang tanah di Kabupaten Pati adalah 212.949,72 ton. Jika $30 \%$ dari kacang tanah berupa kulit, maka dengan produksi tersebut akan dihasilkan limbah kulit kacang tanah sekitar 63.884, 92 ton. Limbah kulit kacang tanah dengan jumlah tersebut merupakan jumlah yang cukup besar dengan kandungan selulosa yang tinggi.

Untuk memberi kekutan pada kertas, perlu ditambahkan keratin bulu ayam karena keratin bulu ayam memiliki struktur $\alpha$-helik dan di dalamnya terdapat sembilan asam amino sistein (C) dari total 98 residu asam amino dan 6 residu sistein ini akan membentuk jembatan disulfida dan memberi kekuatan mekanik pada bulu (Lehninger, 1982). Menurut Badan Pusat Statistik (BPS) Provinsi Jawa Tengah, pada tahun 2012 terdapat 142.687.132 ekor ayam yang dipotong. Sehingga terdapat potensi besar sebagai bahan baku pembuatan 
keratin. Jika diasumsikan rerata berat ayam pedaging yang dipotong $1.5 \mathrm{~kg}$ dan sebesar enam persen dari bobot badan adalah bobot bulu, maka diperkirakan pada tahun tersebut dihasilkan 12.841.841,88 kg limbah bulu ayam. Bulu ayam mengandung protein sebesar $70-80 \%$ terutama disusun oleh keratin. Sehingga keratin dari bulu ayam layak digunakan sebagai bahan tambahan pembuatan paper bag karena sifat dari keratin yang memiliki struktur kuat sehingga akan menyokong kekuatan pada kertas.

Bahan utama dalam proses pembuatan kertas adalah bubur kertas atau yang dikenal dengan istilah pulp. Pada umumnya pulp terbuat dari bahan baku kayu yang mengalami beberapa tahapan proses, sehingga pada akhirnya berubah menjadi bubur kertas yang prosesnya disebut dengan pulping. Proses pembuatan pulp ada dua macam yaitu secara kimia (chemical pulping) dan proses mekanikal (mechanical pulping). Proses kimia terdiri dari tiga macam yaitu proses soda, proses sulfat, dan proses sufit. Bahan kimia yang digunakan pada proses sulfat yaitu $\mathrm{NaOH}$, $\mathrm{Na}_{2} \mathrm{~S}, \mathrm{CaO}, \mathrm{Na}_{2} \mathrm{SO}_{4}$. Keunggulan proses sulfat yaitu cocok untuk semua jenis bahan serat, kekuatan lembaran pulp relatif tinggi, delignifikasi berlangsung cepat dengan degradasi selulosa relatif kecil, daur ulang bahan kimia relatif mudah.

Pada pembuatan kertas, penambahan larutan $\mathrm{NaOH}$ atau $\mathrm{CaO}$, berfungsi untuk melarutkan lignin saat proses pembuburan (pulping) sehingga mempercepat proses pemisahan dan pemutusan serat (Sucipto dkk, 2009). Menurut hasil penelitian Paskawati dkk, 2010, bahwa konsentrasi larutan $\mathrm{NaOH}$ yang paling baik $15 \%$, untuk melarutkan selulosa, pemakaian larutan $\mathrm{NaOH}$ yang berlebihan akan menyebabkan selulosa terdegradasi. Menurut Nasution
(2010) dari hasil penelitian pemasakan jerami padi untuk basis 100 liter larutan $\mathrm{NaOH} \mathrm{5 \%}$ untuk pemasakan $9 \mathrm{~kg}$ jerami padi kering diperoleh sekitar 5,5 $\mathrm{kg}$ pulp atau rendemen sekitar 65,6\%. Sedangkan Pada penelitian (Muksin, 2007) $\mathrm{CaO}$ digunakan untuk pembuatan pulp secara kumiawi dengan konsentrasi 10\%. Menurut hasil penelitian Asngad Aminah dkk (2014) bahwa ada perbedaan ketahanan tarik, ketahanan sobek, maupun hasil uji organoleptik kertas seni dari ruput gajah melalui Chemical Pulping (proses Kimia) dengan menggunakan $\mathrm{NaOH}$ dan $\mathrm{CaO}$.

Berdasarkan latar belakang di atas maka rumusan masalah pada penelitian ini: (1) bagaimana ketahanan tarik dan ketahanan sobek kertas dari kulit kacang dengan penambahan bulu ayam melalui chemical pulping menggunakan $\mathrm{NaOH}$ dan $\mathrm{CaO}$ yang berbeda?; serta (2) bagaimana uji organoleptik karakteristik kertas dari kulit kacang dengan penambahan bulu ayam melalui chemical pulping menggunakan $\mathrm{NaOH}$ dan $\mathrm{CaO}$ yang berbeda?. Tujuan penelitian ini adalah untuk mengetahui: (1) ketahanan tarik dan ketahanan sobek kertas dari kulit kacang dengan penambahan bulu ayam melalui chemical pulping menggunakan $\mathrm{NaOH}$ dan $\mathrm{CaO}$; serta (2) uji organoleptik kertas dari kulit kacang dengan penambahan bulu ayam melalui chemical pulping menggunakan $\mathrm{NaOH}$ dan $\mathrm{CaO}$ yang berbeda.

\section{METODE PENELITIAN}

Penelitian telah dilaksanakan pada bulan Oktober 2013 -Pebuari 2014 di Laboratorium Biokimia Prodi. Pend. Biologi UMS. Metode penelitian yang digunakan adalah metode penelitian eksperimental. Rancangan lingkungan yang digunakan Rancangan Acak Lengkap (RAL) dengan pola faktorial dan dua ulangan. Penelitian digunakan 2 faktor, yaitu: Faktor 1: Jenis 
Larutan (J) terdiri 2 taraf yaitu, $\mathrm{J}_{1}: \mathrm{NaOH}$ dan $\mathrm{J}_{2}: \mathrm{CaO}$, sedang faktor 2: Perbandingan komposisi limbah bulu ayam dan kulit kacang tanah terdiri dari 3 taraf, yaitu: A1: (Bulu ayam 50\% : Kulit Kacang 50\%), A2: (Bulu ayam 40\% : Kulit Kacang 60\%), dan A3: (Bulu ayam 30\% : Kulit Kacang 70\%).

Adapun prosedur penelitian meliputi: (a) Tahap Persiapan; (b) Tahap Pelaksanaan Pembuatan kertas, dan (c) Tahap Pengujian fisik kertas meliputi Uji Ketahanan Tarik dan Uji ketahanan sobek dengan menggukan Dumblle untuk memotong kertas. Untuk mengukur bagian tengah sample dengan menggunakan Micrometer dengan mengaktifkan program Universal Testing Machined.

Pengujian sensoris dilakukan oleh 20 orang panelis dengan memberikan sampel dari masing-masing perlakuan yang diujikan pada lembar angket yang telah disediakan. Dalam penelitian ini, analisis yang digunakan adalah deskriptif kualitatif yang digunakan untuk melakukan uji ketahanan tarik, ketahanan sobek, dan uji sensoris kertas.

\section{HASIL DAN PEMBAHASAN}

Hasil penelitian pemanfaatan kulit kacang dan bulu ayam sebagai alternatif bahan dalam pembuatan kertas melalui chemical pulping (proses kimia) dengan menggunakan $\mathrm{NaOH}$ dan $\mathrm{CaO}$ diperoleh data hasil pengujian ketahan tarik dan ketahanan sobek kertas. Pengujian ketahanan tarik dan ketahanan sobek kertas tersebut dilaksanakan di Universitas Gadjah Mada Yogyakarta dengan menggunakan alat uji Testing Machine dan uji sensori yang dilakukan oleh 20 orang panelis yaang terdiri atas mahasiswa Universitas
Muhammadiyah Surakarta dan masyarakat umum. Hasil uji ketahanan tarik, ketahanan sobek dan uji sensori adalah sebagai berikut.Tabel 1. Hasil Ketahanan Tarik dan Ketahanan Sobek Kertas dari Bulu Ayam dan Kulit Kacang dengan Menggunakan $\mathrm{NaOH}$ dan $\mathrm{CaO}$

Tabel 1. Hasil Ketahanan Tarik dan Ketahanan Sobek Kertas dari Bulu Ayam dan Kulit Kacang dengan Menggunakan $\mathrm{NaOH}$ dan $\mathrm{CaO}$

\begin{tabular}{ccc}
\hline Perlakuan & $\begin{array}{c}\text { Kekuatan Tarik } \\
(\mathrm{N})\end{array}$ & Kekuatan Sobek $(\mathrm{N})$ \\
\hline $\mathrm{J}_{1} \mathrm{~A}_{1}$ & $2.3531^{*}$ & $9.2773 \#$ \\
$\mathrm{~J}_{1} \mathrm{~A}_{2}$ & 2.2732 & 6.9535 \\
$\mathrm{~J}_{1} \mathrm{~A}_{3}$ & 0.9657 & 3.9324 \\
$\mathrm{~J}_{2} \mathrm{~A}_{1}$ & 2.1591 & 3.4954 \\
$\mathrm{~J}_{2} \mathrm{~A}_{2}$ & 1.0875 & 1.9079 \\
$\mathrm{~J}_{2} \mathrm{~A}_{3}$ & $0.7433 * *$ & $1.6277 \# \#$ \\
\hline
\end{tabular}

Keterangan:

* : kekuatan tarik yang paling kuat

** : kekuatan tarik yang paling lemah

\# : kekuatan sobek yang paling kuat

\#\# : kekuatan sobek yang paling lemah

Tabel 2. Hasil Uji Sensoris Kertas dari Bulu Ayam dan Kulit Kacang dengan Penambahan $\mathrm{NaOH}$ dan $\mathrm{CaO}$

\begin{tabular}{cccc}
\hline \multicolumn{4}{c}{ Uji Sensoris } \\
\hline Perlakuan & Tekstur & $\begin{array}{c}\text { Kenampakan } \\
\text { Serat }\end{array}$ & Kesukaan \\
\hline J1A1 & Kasar & Tampak & Netral \\
J1A2 & Kasar & Tampak & Netral \\
J1A3 & Kasar & Tampak & Netral \\
J2A1 & Kasar & Tampak & Netral \\
J2A2 & Kasar & Tampak & Netral \\
J2A3 & Kasar & Tampak & Netral \\
\hline
\end{tabular}


Bioeksperimen

Volume 2 No. 1, (Maret 2016)

ISSN 2460-1365

\section{PEMBAHASAN}

Hasilujiketahanantarikdanketahanan sobek kertas dari limbah bulu ayam dan kulit kacang dengan menggunakan $\mathrm{NaOH}$ dan $\mathrm{CaO}$ sebagai berikut:

\section{Ketahanan Tarik}

Hasil rata-rata ketahanan tarik kertas dari limbah bulu ayam dan kulit kacang dapat disajikan dalam bentuk diagram seperti tercantum pada Gambar 1 .

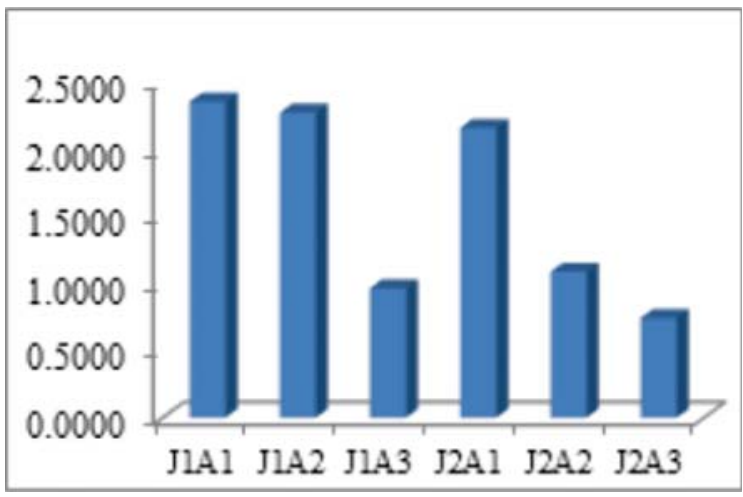

Gambar 1. Uji Ketahanan Tarik Kertas

Berdasarkan hasil penelitian (Gambar 1) pada uji ketahanan tarik kertas dari Limbah Bulu Ayam dan Kulit Kacang dengan menggunakan $\mathrm{NaOH}$ dan $\mathrm{CaO}$, diketahui bahwa ketahanan tarik paling tinggi pada perlakuan $\mathrm{J}_{1} \mathrm{~A}_{1}$ (Bahan kimia $\mathrm{NaOH}$ 15\% dan Bulu ayam 50\%: Kulit Kacang 50\%) dengan rata-rata ketahanan $2.3531 \mathrm{~N}$, diikuti dengan $\mathrm{J}_{1} \mathrm{~A}_{2}(2.2732 \mathrm{~N}), \mathrm{J}_{2} \mathrm{~A}_{1}(2.1591$ $\mathrm{N}), \mathrm{J}_{2} \mathrm{~A}_{2}(1.0875 \mathrm{~N}), \mathrm{J}_{1} \mathrm{~A}_{3}(0.9657 \mathrm{~N})$, $\mathrm{J}_{2} \mathrm{~A}_{3}(0.7433 \mathrm{~N})$. Ketahanan tarik yang berbeda dikarenakan setiap perlakuan menggunakan limbah bulu ayam dan kulit kacang dengan perbandingan prosentase yang berbeda. Perlakuan yang memiliki nilai kekuatan tarik yang paling tinggi yaitu pada perlakuan $\mathrm{J}_{1} \mathrm{~A}_{1}$ (prosentase bulu ayam dan kulit kacang tanah 50\%:50\%). Pada kertas dengan komposisi serat dan selulosa yang seimbang membuat ikatan serat yang terbentuk lebih panjang karena menurut (Wulandari, 2013) kandungan serat pada bulu ayam sebanyak $82,2 \%$ dan menurut (Deptan, 2008)selulosa pada kulit kacang tanah sebanyak 63,5\%. Untuk komposisi serat dan selulose yang tidak seimbang yakni memiliki kandungan selulosa yang lebih banyak, maka memiliki ikatan serat yang lebih pendek karena komposisi bulu ayam yang lebih sedikit sehingga membuat ikatan serat menjadi pendek dan kertasnya menjadi tidak solid. Menurut Yosephine, (2012). Kandungan serat pendek yang semakin banyak dibandingkan dengan serat panjang dari pulp menyebabkan kertas yang terbentuk menjadi lebih rapuh.

Ketahanan tarik juga dipengaruhi oleh bahan kimia yang digunakan, karena bahan kimia tersebutberfungsi untuk melarutkan lignin yang mengakibatkan serat mudah hancur pada saat penggilingan. Sehingga serat tersebut dengan mudah dapat membentuk ikatan serat satu sama lain. Selain itu, pelarutan lignin oleh $\mathrm{NaOH}$ danCaO menyebabkan bereaksi dengan lignin dan akan menyebabkan selulosa terdegradasi dan serat akan rusak, tidak dapat terjalin sempurna. Rusaknya serat akan mempengaruhi ikatan antar serat yang terjadi, karena jika ikatan antar serat kurang maka ketahanan tarik kertas juga lemah.Panjang serat yang terbentuk pada saat pulping jugaakan mempengaruhi ikatan antar serat, karena serat yang pendek mempunyai daya ikat serat yang lebih tinggi dibandingkan dengan serat yang panjang. Ikatan antar serat yang terbentuk akan mempengaruhi 
ketahanan tarik, semakin besar kekuatan ikatan antar serat maka ketahanan tarik juga makin besar.

Homogenitas perekat juga mempengaruhi ketahanan tarik kertas, karena PVAc (perekat) berfungsi untuk merekatkan ikatan antar serat. Adanya perekat ini menyebabkan tiap lembar kertas menjadi kuat dan tidak mudah putus ketika direntangkan dan ditarik pada sisi-sisinya secara berlawanan. Disamping homogenitas, Perekat juga dipengaruhi oleh cara penggilingannya. Karena penggilingan berfungsi untuk menghomogenkan perekat dan mempengaruhi kualitas ikatan antar serat. Semakin pulp tergiling secara homogen, maka ikatan antar serat semakin tinggi, sehingga katahanan tarik kertas semakin tinggi pula. Perbedaan ketahanan tarik juga dapat disebabkan tidak ratanya ketebalan kertas waktu pencetakan, karena pencetakan dilakukan secara manual.

Menurut Casey (1981), perbedaan ketahanan tarik kertas disebabkan karena perbedaan panjang serat yang menyusun kertas tersebut dan adanya metode surface sizing (metode mengisi permukaan lembaran kertas, biasanya dengan pati). Sedangkan menurut Paskawati (2010), Bahwa faktor yang mempengaruhi kekuatan kertas yaitu kekuatan individual kertas, ikatan antar serat, dan panjang serat.

\section{Ketahanan Sobek}

Hasil rata-rata ketahanan sobek dapat dilihat pada Gambar 2.

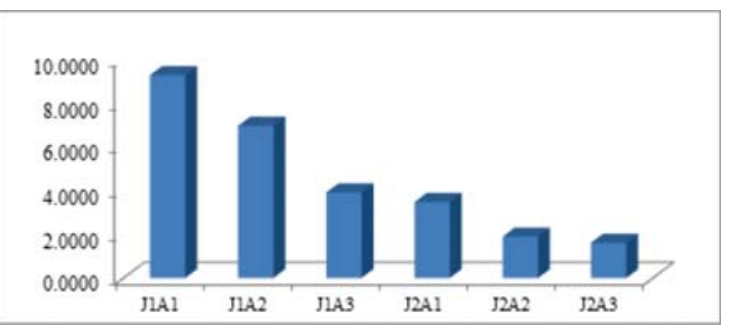

Gambar 2. Uji Ketahanan Sobek Kertas

Berdasarkan hasil penelitian (diagram 2) pada uji ketahanan sobek kertas dari Limbah Bulu Ayam dan Kulit Kacang dengan Menggunakan $\mathrm{NaOH}$ dan $\mathrm{CaO}$, diketahui bahwa ketahanan sobek paling tinggi pada perlakuan $\mathrm{J}_{1} \mathrm{~A}_{1}$ (Bahan kimia $\mathrm{NaOH} 15 \%$ dan Bulu ayam $50 \%$ : Kulit Kacang 50\%)dengan rata-rata ketahanan $9.2773 \mathrm{~N}$, diikuti dengan $\mathrm{J}_{1} \mathrm{~A}_{2}$ $(6.9535 \mathrm{~N}), \mathrm{J}_{1} \mathrm{~A}_{3}(3.9324 \mathrm{~N}), \mathrm{J}_{2} \mathrm{~A}_{1}(3.4954 \mathrm{~N})$, $\mathrm{J}_{2} \mathrm{~A}_{2}(1.9079 \mathrm{~N}), \mathrm{J}_{2} \mathrm{~A}_{3}(1.6277 \mathrm{~N})$. Ketahanan sobek yang berbeda dikarenakan setiap perlakuan menggunakan Limbah Bulu Ayam dan Kulit Kacang dengan perbandingan prosentase yang berbeda. Perlakuan yang memiliki nilai kekuatan tarik yang paling tinggi yaitu pada perlakuan $\mathrm{J}_{1} \mathrm{~A}_{1}$ (prosentase bulu ayam dan kulit kacang tanah $50 \%$ : 50\%).Hal ini karena kandungan selulosa pada kulit kacang tanah sebesar 63,5\% (Deptan, 2008) seimbang dengan serat dari bulu ayam dengan kandungan serat sebesar 82,2\% (Wulandari, 2013). Komposisi yang seimbang tersebut membuat ikatan serat lebih panjang dan solid sehingga ketahanan sobeknya tinggi dan serat panjang pada bulu ayam dapat seimbang dengan serat pendek yang dimiliki selulosa sehingga ikatan antar serat lebih panjang dan kekuatan sobeknya lebih kuat 
Nilai kekuatan sobek yang rendah terdapat pada perlakuan yang komposisi limbah bulu ayam yang rendah, dan komposisi limbah kulit kacang tanah tinggi. Hal ini disebabkan karena kandungan selulosa yang memiliki ikatan serat pendek lebih banyak sehingga menyebabkan kertas lebih keras dan mudah rapuh. Menurut penelitian Yosephine (2012) semakin tinggi amilopektin atau selulosa maka kekuatan sobeknya semakin rendah dan jika keadaan keadaan kertas keras atau getas menyebabkan kertas mudah sobek. Juga didukung hasil penelitian Retnoningtyas (2012), bahwa keadaan kertas yang keras dan getas inilah yang menyebabkan kertas menjadi mudah disobek.

Hmogenitas perekat (P VAc) juga berpengaruh terhadap ikatan antar serat, karena adanya perekat tersebut menyebabkan tiap lembar kertas menjadi kuat dan tidak mudah robek. Pada penelitian, perbedaan ketahanan sobek juga dapat disebabkan tidak ratanya ketebalan kertas waktu pencetakan, karena pencetakan dilakukan secara manual.

Menurut Menurut Haygreen dan Bowyer (1986), bahwa ketahanan sobek dipengaruhi oleh ikatan antar serat tetapi lebih sangat dipengaruhi oleh keterpaduan serat masing-masing. Sedangkan menurut Paskawati, (2010), kekuatan individual kertas, ikatan antar serat, dan panjang serat mempengaruhi kekuatan kertas.

\section{Pengujian Sensoris}

Pengujian sensoris yang dilakukan meliputi tekstur, kenampakan serat dan tingkat kesukaan masyarakat terhadap produk. Pengujian organoleptik dilakukan peda 20 orang panelis dari berbagai kalangan pekerjaan. Adapun hasil uji sensoris dapat dilihat pada table 2 di atas.

a. Tekstur

Berdasarkan hasil penelitian menunjukkan bahwa rata-rata pada masing-masing perlakuan menunjukkan tekstur kertas dari bulu ayam dan kulit kacang tanah memiliki tekstur yang kasar. Hal tersebut disebabkan oleh serat-serat dari bulu ayam yang sulit hancur karena memiliki ikatan serat yang panjang sehingga membuat ikatannya solid sehingga tidak mudah hancur dan menyebankan teksturnya kasar. Selain itu kulit kacang tanah yang partikelnya juga sulit hancur karena kandungan selulosa yang juga tinggi menyebabkan tekstur kertas semakin terlihat kasar. Menurut penelitian (Sucipto, 2009), tekstur permukaan dipengaruhi oleh teknik pencetakan dan ukuran serat. Pada pembuatan kertas pada penelitian, pencetakan menggunakan screen sehingga permukaan kertas tidak rata, berbeda dengan kertas dipasaran yang menggunakan metode pressing sehingga kertas yang dihasilkan lebih halus dan rata

Faktor lain yang menyebabkan kertas tersebut kasar yaitu pada saat penggilingan. Pulp yang digiling dengan waktu yang lebih lama menyebabkan komposisi pulp lebih homogen karena bulu ayam dan kulit kacang tanah dapat hancur sehingga tekstur yang nampak menjadi lebih halus dari pada pulp yang digiling dengan waktu yang kurang lama. 
b. Kenampakan Serat

Berdasarkan hasil penelitian menunjukkan bahwa kenampakan serat kertas pada semua perlakuan nampak, terutama pada perlakuan pada perlakuan $\mathrm{J}_{1} \mathrm{~A}_{1}$ (prosentase bulu ayam dan kulit kacang tanah 50 $\%$ : 50\%). Hal itu karena ikatan serat yang terbentuk panjang yaitu dengan komposisi bulu ayam dan kulit kacang tanah yang seimbang (50\%: 50\%). Ikatan serat yang panjang tersebut menyebabkan serat pada kertas menjaditerlihatkarenabuluayamyang sulit hancur sehingga membuat serat tersebut nampak ketika kertas sudah dicetak. Pencetakan kertas tersebut berpengaruh terhadap kenampakan serat yang ada pada kertas. Menurut penelitian (Sucipto, 2009), Kenampakanpada kertas seni pelepah pisang hasilpenelitian kelihatan lebih unik denganmenampilkan serat-serat yang panjangdengan permukaan yang tidak rata.Menurut Fegel dan Wegener (1995), proses pencetakan juga mempengaruhi hasil pada kenampakan serat.

Munculnya serat ini juga dipengaruhi oleh bahan kimia $(\mathrm{NaOH}$ dan $\mathrm{CaO}$ ) yang berperan dalam pemisahan dan pemutusan serat yang merupakan larutan alkali pada proses pemotongan serat tidak sempurna sehingga bulu ayam sulit dihancurkan yang menyebabkan serat masih tetap tampak ketika pencetakan.

c. Kesukaan

Kesukaan terhadap kertas tergantung pada tekstur, dan kenampakan serat yang ada. Berdasarkan hasil uji sensoris kertas dari bulu ayam dan kulit kacang, kesukaan masing-masing panelis bervariasi, tergantung pada tekstur, dan kenampakan serat. Rata-ratapanelis menyukai semua kertasdengan nilai 2,3 (netral), yang menarik perhatian panelis tekstur dan kenampakan serat yang tampak pada perlakuan tersebut.

d. Daya Terima Masyarakat

Daya terima masyarakat atau dapat disebut parameter overall (keseluruhan) merupakan parameter penerimaan umum yang dilakukan untuk mengetahui penerimaan konsumen secara menyeluruh terhadap suatu produk (Martini, 2009). Hasil uji organoleptik menunjukkan bahwa daya terima panelis yang paling dominan pada semua perlakuan keju yaitu agak suka. Daya terima masyarakat dipengaruhi oleh uji organoleptik yang telah dilakukan sebelumnya dan tingkat kesukaan panelis yang berbeda. Namun, berdasarkan Gambar 4.3 bahwa pada perlakuan $\mathrm{LK}_{2}$ memiliki range rata-rata paling tinggi. Hal ini disebabkan oleh aroma lemon pada perlakuan $\mathrm{LK}_{2}$ sangat disukai panelis. Sedangkan range rata-rata terendah pada perlakuan $\mathrm{LK}_{1}$, karena aroma lemon yang dihasilkan kurang tajam sehingga panelis hanya memilih kriteria agak suka pada keju atau soy cheese.

\section{KESIMPULAN}

Berdasarkan data dan pembahasan dapat diambil kesimpulan sebagai berikut:

1. Ada perbedaan hasil kertas dari kulit kacang dan bulu ayam melalui chemical pulping dengan menggunakan $\mathrm{NaOH}$ dan $\mathrm{CaO}$ pada ketahanan tariknya dan ketahanan sobeknya adalah $\mathrm{J}_{1} \mathrm{~A}_{1}(50 \%$ 
limbah bulu ayam: 50\% limbah kulit kacang tanah) rata-rata ketahanan tariknya 2,3531 $\mathrm{N}$ dan ketahanan sobeknya 9,277311 N.

2. Tidak ada perbedaan hasil kertas dari kulit kacang dan bulu ayam melalui chemical pulping dengan menggunakan $\mathrm{NaOH}$ dan $\mathrm{CaO}$ pada uji organoleptik pada semua perlakuan.

\section{DAFTAR PUSTAKA}

Asngad, A. 2014. Pemanfaatan Rumput Gajah (Pennisetum purpureum) untuk Pembuatan Kertas Melalui Chemical Pulping Menggunakan $\mathrm{NaOH}$ dan $\mathrm{Na}_{2} \mathrm{CO}_{3}$. Prosiding Seminar Nasional Pendidikan Biologi Program Studi Pendidikan Sains Pascasarjana UNS.

Deptan.2008. Pemanfaatan Limbah Sebagai Bahan Pakan Ternak.http://jajo66. files.wordpress.com. Diakses 12 Okober 2014.

Fengel, D dan G Wengener.1995. Kayu Kimia Ultrasruktur dan Reaksi-Reaksi. Penerjemah H. Sastrohamidjojo. Yogyakarta: Gadjah Mada University.

Haygreen, Jhon G \& Jim L Bowyer. 1989. Hasil Hutan dan Ilmu Kayu penerjemah Sutjipto A Hadikusumo. Yogyakarta: Gadjah Mada University Press.

Murni, R, dkk. 2008. Pemanfaatan Limbah sebagai Bahan Pakan Ternak. Laboratorium Makanan Ternak Fakultas Peternakan Universitas Jambi. Jambi.

Nasution, Zainal Abidin. 2010. Pembuatan dan Karakteristik Dari Limbah Jerami Padi Untuk Tatakan Gelas Cetak Tangan. Penelitian Pada Balai Riset
Standarisasi Industri Medan Vol. 45 No. 1 hal. 16-21.(Diakses pada 2 Oktober 2014).

Paskawati, Y. A., Susyana., Antaresti., E. S. Retnoningtyas. 2010. Pemanfaatan Sabut Kelapa Sebagai Bahan Baku Pembuatan Kertasm Komposit Alternatif. Jurnal Widya Teknik

Prabawati, Susy Yunita dan Abdul Gani Jaya. 2008. Pemanfaatan Sekam Padi dan Pelepah Pohon Pisang sebagai Bahan Alternatif Pembuat Kertas Berkualitas. Aplikasia, Jurnal Aplikasi llmu-ilmu Agama, Vol. IX, No. 1 Juni 2008

Purnawan.2012. Pemanfaatan Limbah Ampas Tebu Untuk Pembuatan Kertas Dekorasi Dengan Metode Organosolv. Jurnal EKOSAINS.Vol. 4. No. 2.

Syamsu , Khaswar, dkk. 2014. Kajian Proses Produksi Pulp Dan Kertas Ramah Lingkungan Dari Sabut Kelapa. Jurnal Teknologi Pertanian Vol.9 No.1 2014.

Sucipto., S. Wijana., dan E. Wahyuningtyas. 2009. Optimasi Penggunaan $\mathrm{NaOH}$ dan Tapioka Pada Produksi Kertas Seni Dari Pelepah Pisang. Jurnal Teknologi Pertanian

Wulandari, Winarto Adi dan Sri Rahayu.2013. Kecernaan lemak dan energi konsentrat monogastrikberbasis hidrolisat tepung bulu ayam secara in vitro. Jurnal Ilmiah Peternakan. Vol:1(2).

Yosephine, allita.2012. Pemanfaatan Ampas Tebu dan Kulit Pisang Dalam Pembuatan Kertas Serat Campuran. JurnalTeknik Kimia 
Indonesia.Vol.11 No. 2 (Diakses pada 2 Oktober 2014).

Zulfikar T, M., Sri Kumalaningsih, dan Susinggih Wijana. Teknologi Produksi Pulp dari Serat Daun
Nenas(Kajian Variasi Pelarut CaO,

Suhu dan Waktu Pemasakan). Jurnal Penelitian Teknologi Industri Pertanian. 